\title{
ПРАВОВЕ РЕГУЛЮВАННЯ ФОРМУВАННЯ ТА ВИКОРИСТАННЯ ПУБЛІЧНИХ БАЗ ДАНИХ
}

\author{
ССІМОВ Сергій Сергійович - кандидат юридичних наук, доцент, доцент \\ кафедри адміністративного та інформаційного права Національного університету \\ «Дьвівська політехніка" \\ УДК 342.982.3(477) \\ DOI 10.32782/LAW.UA.2020.3.9
}

В статье исследуются проблемъ правового регулирования формирования и использования публичных баз данных с позиции действуюшего инбормационного законодательства в контексте европейской интеграиии Украинъ по применению общенаучнъх u специиально-юридических методов исследования правовъх явлений. Предпосъилкой бормирования и использования публичнъхх баз даннъхх являются публичные интересъ, признанъие государством и обеспеченнъие правом общественно значимые потребности в систематизированном учете в иифровой борме наиболее важных для государства сведений с иелью дальнейшего использования в деятельности органов публичной власти. Анализируется легальное определение понятия «база даннъгх и раскрьгваются различные интерпретации этого понятия, которвие разделенъг на три группь в зависимости от информативности и содержания. Рассматривается соотношение баз данньх и регистрационных учетов в контексте инбормационных ресурсов деятельности органов государственной и местной власти, правовъге режимы бормирования и использования баз даннъих. Указано, ито фбункиионирование баз даннъх имеет технологические основъ, это, в свою очередь, требует юридической интерпретации и включения в сберу действия права. Раскрыто соотношение понятий «база даннъх» и «банк даннъх», указано в отдельнъгх случаях понятие рассматривают как равнозначнъле, в других как составная часть. Разрозненность правового регулирования приводит к смешению правовых режимов баз данных и различных видов инфбормации учетного характера, подменъ понятий. Несовершенство законодательства в области публичных баз данных выраженная в отсутствии единьгх требований и правил формирования и использования публичньх баз даннъхх, в неопределенности законодательнъх дебинииий понятия «база даннъхх в публичной сфере. В иелях совершенствования правового регулирования в области публичнъгх баз даннъх необходимо принятие законодательного акта, создает нормативно-правовую основу для бормирования и использования баз данных в сбере публичного управления.

Установлено, что в общем виде, в зависимости от подхода к правовому регулированию баз даннъхх, совокупность нормативньх актов в этой области можно представить следуюшим образом: первая группа - законь и подзаконные нормативные актъл, закрепляющие правовой режим конкретной базы даннъхх как инбормационного ресурса; вторая группа - административнъе регламенть предоставления услуг по ведению баз даннъих и по предоставлению инбормации из баз даннъгх; третью группу нормативнъих актов составляют те, в которьх только упоминается необходимость создания и ведения баз даннъих в определенной сбере общественнъих отношений.

Ключевъе слова: база даннъх, банк даннъхх, инбормационная система, инбормационнъле ресурсъи, публичная власть, законодательство, правовое регулирование. 
Постановка проблеми

Удосконалення інформаційних технологій і збільшення масивів інформаційних ресурсів істотно змінили підходи до розуміння ролі і значення баз даних у реалізації державної інформаційної політики. Бази даних формуються i використовуються в ycix сферах суспільного життя. Переваги цієї форми організації інформації дозволяють розглядати бази даних як важливий інструмент упорядкування державних і місцевий інформаційних ресурсів. Дослідження правової природи баз даних і проблем правового регулювання проводилося переважно в рамках науки цивільного права. Однак потреби у подальшому розвитку та вдосконаленні законодавства в галузі баз даних ставлять перед юридичною наукою завдання дослідження правової природи як об'єкта інформаційних правовідносин комплексного характеру та розробки основ правового регулювання для створення та використання публічних баз даних.

\section{Аналіз дослідження проблеми}

Бази даних як об'єкт правовідносин досліджуються в працях учених: Г. О. Андрощука, I. В. Арістової, В. Д. Базилевича, В. М. Брижка, Н. П. Бортник, В. Д. Гавловського, Р. А. Калюжного, О. М. Кохановської, А. І. Марущака, В. А. Ортинського, О. Д. Святоцького, О. В. Сосніна, В. П. Тихого, М. Я. Швеця і інших. Реалізація Угоди про асоціацію України та Европейського Союзу потребує комплексного аналізу правового регулювання баз даних як об'єктів правової охорони з метою ефективної адаптації національного законодавства.

Мета статті - дослідження правового регулювання формування та використання публічних баз даних.

\section{Виклад основного матеріалу}

Сьогодні інформаційна діяльність органів виконавчої влади - це особливий, специфічний вид їхньої функціональної діяльності, зазначає В. А. Ортинський, спрямований на виконання завдань інформаційного забезпечення власної діяльності, інформування громадян, суспільства про свою роботу та ії результати, інформаційне обслуговування громадян і організацій [1, с. 4].Інформаційне забезпечення здійснюється через використання баз даних. Правове регулювання суспільних відносин 3 формування та використання публічних баз даних здійснюеться за допомогою нормативно-правових актів різної юридичної сили: законів, постанов Кабінету Міністрів України, актів органів виконавчої влади і органів місцевого самоврядування.

У загальному вигляді, в залежності від підходу до правового регулювання баз даних, сукупність нормативних актів у цій галузі можна представити таким чином. Перша група - закони та підзаконні нормативні акти, що закріплюють правовий режим конкретної бази даних як інформаційного ресурсу. Друга група - адміністративні регламенти надання послуг з ведення баз даних і $з$ надання інформації з баз даних. Третю групу нормативних актів складають ті, у яких тільки згадується необхідність створення та ведення баз даних у певній сфері суспільних відносин.

Третя група нормативних актів за кількісним складом перевищує інші, що свідчить про труднощі у встановленні правового режиму публічних баз даних і нормативному закріпленні порядку роботи 3 таким об'єктом. Норми права, що закріплюють особливості формування та використання публічних баз даних, містяться в багатьох галузях права, що підкреслює комплексний характер. Правове регулювання створення та використання баз даних органів публічної влади носить несистемний характер. Викликано це тим, що законодавство в цій сфері не має єдиних основ, що утворюють систему правового регулювання

Нормативно-правові акти, які зачіпають окремі аспекти правового регулювання публічних баз, характеризується неоднозначністю підходів до питань створення та використання баз даних, невизначеністю термінології, відсутністю єдиних умов забезпечення безпеки баз даних.

Аналіз нормативно-правових актів у галузі формування і використання публічних баз дозволяе виділити основні проблеми і 


\section{Адміністративне право}

недоліки законодавчого регулювання суспільних відносин.

Відсутність однаковості в нормативних визначеннях поняття «база даних» у публічно-правовій сфері. Незважаючи на закріплення в законі України «Про Національну програму інформатизації» легального визначення, термінологічна єдність у спробах введення власних правових дефініцій даного терміну в галузевих нормативно-правових актах не виявляється [2]. У прагненні підкреслити в нормі специфіку бази даних законодавець допускає термінологічну невідповідність в розумінні цього об'єкта. Усі законодавчі визначення досліджуваного поняття можна розділити на кілька груп.

Першу групу складають визначення, які засновані на визначенні бази даних, закріпленої в раніше чинному законодавстві. Наприклад, згідно Концепції створення єдиної автоматизованої паспортної системи база даних - це незалежна від прикладних програм сукупність даних, що організована за певними правилами, які передбачають загальні принципи описання, зберігання i маніпулювання даними [3].

Аналогічні формулювання містяться в наказі Державного комітету статистики та Міністерства України у справах науки та техніки «Про затвердження типових форм первинного обліку науково-інформаційної діяльності та про порядок їх використання і застосування», в наказі Міненерго «Інструкція про порядок складання звіту про використання програмних продуктів i комп'ютерних мереж на 1 січня 1997 року за формою № 3-інф»та інших нормативних актах [4].

У визначеннях другої групи підкреслюється, що база даних - це сукупність або набір даних. Наприклад, у підзаконних актах база даних описується як сукупність взаємопов'язаних даних на цифрових носіях як централізоване сховище інформації, яке функціонує на основі системи управління базами даних. База даних - один або декілька структурованих файлів даних [5].

У представлених визначеннях законодавець виділяє лише деякі ознаки бази даних, але не розглядає їх у єдності. Це електронна форма подання інформації (дані), наявність цифрового носія, централізація (систематизація) інформації з метою тривалого зберігання, можливість одночасного використання великим числом користувачів, застосування спеціального програмного комплексу - системи управління базою даних. Такі визначення не дозволяють повністю розкрити правову природу та сутність даного об'єкту, вибудувати правовий режим.

У визначеннях третьої групи акцент зроблений на характеристиці баз даних як реєстраційно-облікових документів. База даних Засвідчувального центру, у якій зберігається реєстр Засвідчувального центру, інформаційно-довідкова, технологічна та інша службова інформація, потрібна для функціонування програмнотехнічного комплексу Засвідчувального центру [6]. В окремих документах уточнюється, що ведення бази даних полягає в здійсненні сукупності дій занесення в базу даних відомостей про об'єкти обліку, оновлення і виключення в разі зміни форми обліку.

У визначеннях підкреслюється цільове призначення баз даних як форми електронного подання реєстрової інформації. Їх недоліком є поставлений законодавцем знак рівності між базою даних та інформацією облікового характеру.

у більшості випадків бази даних створюються для структурованого уявлення в електронній формі інформації про об'єкти облікової та реєстраційної діяльності. Це викликано необхідністю системної організації відомостей про юридично значимі факти, події, об’єкти дуже різних сфер суспільного життя. Однак електронна форма не завжди обов'язкова для реєстрової інформації, оскільки реєстри можуть формуватися на паперових носіях без використання обчислювальної техніки. Аналогічно ведення баз даних не обмежується систематизацією реєстрової інформації, оскільки функціональні можливості баз даних набагато ширші.

Облікова форма інформації існує давно. Інформаційні технології створили об'єктивні умови для перекладу у цифровий формат. Тому у визначеннях реєстрова 
інформація підкреслює особливості інформаційного змісту баз даних.

Однією з основних проблем розвитку законодавства в галузі формування та використання публічних баз є відсутність термінологічної єдності, пов'язане 3 тим, що легальне визначення бази даних підкреслює іiі специфіку як компіляції даних, про що йде мова в ст. 433 «Об'єкти авторського права» Цивільного кодексу України [7].

Бази даних віднесені законодавцем до об'єктів авторського права без урахування контенту, що міститься в них. Ознаки бази даних, включені законодавцем в визначення цього поняття, не розкривають сутності. Наприклад, на будь-якому комп'ютері інформація структурована за каталогами та файлами, але не є базою даних.

При розмаїтті підходів до розуміння баз даних у діяльності органів публічної влади досить складно забезпечити узгодженість правозастосовчої практики. 3 метою подальшого розвитку законодавства в досліджуваній галузі, забезпечення стабільності та ефективності потрібно законодавчо закріпити визначення публічної бази даних.

Проблему доцільно вирішувати шляхом розробки юридичної дефініції «публічна база даних» і закріплення в законі, оскільки публічні бази даних $є$ комплексним інформаційним об'єктом права. У нормативно-правових актах відсутні основні ознаки і сутнісні характеристики баз даних. У більшості 3 них термін «база даних» застосовується без розкриття його змісту. Як наслідок термінологічна невизначеність і змішання в законодавстві та правозастосовній діяльності понять бази даних і банку даних, бази даних та інформаційної системи, бази даних та реєстрової інформації різних видів: реєстрів, регістрів, кадастрів, каталогів.

Поширеним способом характеристики бази даних є включення в нормативний акт переліку внесених відомостей. При побудові правового режиму публічних баз даних, оскільки на основі вимог до функціонування бази даних встановлюються заходи для забезпечення безпечного використання, визначаються права і обов'язки осіб, які мають доступ до бази даних, відповідальність за порушення правил роботи.
Незважаючи на те, що вимоги до функціонування баз даних має технологічні засади, неминучою стає необхідність юридичної інтерпретації та включення у сферу дії права. Як приклад можна навести Порядок створення, ведення та доступу до відомостей Єдиної інформаційної бази даних про внутрішньо переміщених осіб, де встановлено обов'язкові вимоги до формування та використання інформаційного ресурсу [8].

Вимоги включають стандартизацію інформації і програмно-технічного забезпечення, цільовий характер використання відомостей, що містяться в базі даних, повнота та достовірність документованої інформації, забезпечення інформаційної безпеки даних, включаючи прийняття системи правових, організаційних і технічних заходів для захисту інформації.

Поряд з поняттям «база даних»у законодавстві активно використовується термін «банк даних»: банк даних про дітей-сиріт, дітей, позбавлених батьківського піклування, і сім'ї потенційних усиновлювачів, опікунів, піклувальників, прийомних батьків, батьків-вихователів; централізований банк даних з проблем інвалідності тощо. Підхід, що відображений в нормативно-правових актах, відповідає загальному розумінню та розмежуванню баз і банків даних у технічній літературі.

Число нормативно-правових актів, у яких правові основи формування на використання інформаційних ресурсів визначаються через правовий режим такої форми організації, як банки даних, не збільшується. У цьому випадку зберігається підхід, закріплений у законодавстві, що діяло раніше.

Відсутня однаковий підхід до закріплення правового режиму баз даних як елемента інформаційної системи. Бази даних є важливим компонентом інформаційних систем, що забезпечує інформаційне наповнення, наявність в інформаційній системі структурованої сукупності інформаційних ресурсів.

Закріплення в нормативно-правовому акті в галузі інформації правового режиму інформаційних систем не допускає двозначності розуміння та термінологічної невідповідності в питанні співвідношення 


\section{Адміністративне право}

баз даних та інформаційних систем. База даних - обов'язковий елемент інформаційної системи, від якого залежить змістовний компонент процесу комунікації. [9]. В окремих нормативних актах бази даних розглядаються як елемент інформаційної системи.

Приведення окремих нормативно-правових актів у відповідність до Закону «Про захист інформацію в інформаційно-телекомунікаційних системах» важливо 3 точки зору необхідності розмежування правового режиму баз даних та інформаційних систем [10]. Інформаційний ресурс може існувати та бути об'єктом правовідносин незалежно від інформаційної системи, елементом якої він є.

Інформаційна система може бути вдосконалена, замінена або виведена з експлуатації, але інформація, що міститься, підлягає зберіганню або використання. Інформаційний ресурс $є$ первинним по відношенню до інформаційної системи та визначає іï межі. Поряд з описом баз даних як елемента інформаційної системи необхідно окремо регламентувати в законодавстві правовий режим, оскільки база даних незалежно від інформаційної системи $є$ самостійним об'єктом правовідносин.

У системі нормативно-правових актів 3 питань формування та використання публічних баз даних можна виділити тенденцію змішання правових режимів баз даних і правових режимів реєстрової інформації різних видів. Часто основи правового режиму баз даних встановлюються за допомогою прямої вказівки на формування відповідного інформаційного ресурсу або віднесення бази даних до реєстрової інформації певного виду.

Віднесення бази даних до певного види реєстру підкреслює інформаційно-ресурсне зміст об'єкта, вказує на форму ведення реєстру та на юридичні підстави та правові наслідки внесення відомостей до бази даних.

Незважаючи на зроблену законодавцем спробу розглянути в єдності правові режими бази даних і різних видів реєстрової інформації (реєстрів, кадастрів, регістрів), хаотичність їх співвідношення в законодавстві є одним з істотних недоліків правового регулювання цієї галузі суспільних відносин.

В одних випадках зазначені поняття розглядаються як рівнозначні (єдиний реєстр юридичних осіб і фізичних осіб-підприємців, свідоцтв про державну реєстрацію продукції, реєстр державної системи сертифікації і інші). В інших - як складові частини.

Закріплення в законодавстві загальних елементів дії права для баз даних і реєстрової інформації має позитивні аспекти. Розрізненість правового регулювання призводить до змішання правових режимів баз даних і різних видів інформації облікового характеру, підміни понять. Розвиток законодавства має будуватися на єдиному підході до включення баз даних у правовий режим реєстрової інформації для виділення особливостей форми ведення таких інформаційних ресурсів.

Огляд нормативних актів показав, що правове регулювання окремих аспектів подання інформаційних ресурсів в систематизованому вигляді за допомогою створення баз даних здійснюється нормативно-правовими актами відомчого характеру. В основному вони визначають порядок формування та ведення баз даних, склад відомостей, порядок доступу до інформації в базах даних, правила роботи, включаючи вимоги до забезпечення безпеки.

Правотворчий процес у сфері державного управління з питань правового забезпечення інформаційних ресурсів і баз даних проходив без урахування загальної державної інформаційної політики та адміністративної реформи. Накопичений масив відомчих нормативних актів $\epsilon$ недостатнім з точки зору нормативної змістовності об'ємним і безсистемним. Така кількість відомчих актів свідчить про потребу баз даних, висуває проблему правової охорони баз даних від неправомірного використання.

Рішення проблеми доцільно почати 3 розробки та нормативно-правового оформлення єдиних правил і вимог до формування та використання баз даних, на основі яких буде розвиватися відомча нормотворчість щодо публічних баз даних органів влади. 3 метою вдосконалення правового 
регулювання в галузі публічних баз даних необхідно прийняти законодавчий акт, що створить нормативно-правову основу для формування та використання баз даних у сфері державного та місцевого управління. Поряд з проблемою правової охорони баз даних в умовах недосконалості законодавства стає актуальним питання захисту прав i законних інтересів осіб в галузі формування і ведення баз даних.

\section{Висновки}

В умовах реалізації Угоди про асоціацію України та Європейського Союзу, що передбачає перехід органів влади на електронний документообіг, характеристикою правової природи публічних баз даних стає ознака публічності, що визначається суспільною значимістю баз даних для використання 3 метою організації міжвідомчої інформаційної взаємодії, надання адміністративних послуг, надання фізичним i юридичним особам доступу до офіційної інформації. Передумовою формування та використання публічних баз даних є публічні інтереси, визнані державою, та забезпечені правом суспільно значущі потреби в систематизованому обліку в цифровій формі найбільш важливих для держави відомостей 3 метою подальшого використання в діяльності органів публічної влади. Можна зробити висновок про недосконалість законодавства в галузі публічних баз даних, вираженій у відсутності єдиних вимог та правил формування та використання публічних баз даних, у невизначеності законодавчих дефініцій поняття «база даних» у публічній сфері. 3 метою вдосконалення правового регулювання в галузі публічних баз даних необхідне прийняття законодавчого акту, що створює нормативно-правову основу для формування та використання баз даних у сфері публічного управління.

\section{Лiтература}

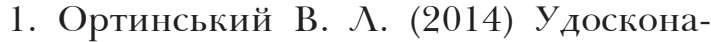
лення державної політики у сфері інформаційних технологій у контексті діяльності органів виконавчої влади. Вісник Нащіонального університету «Аввівсъка політехніка». Юридичні науки. № 801. С. 3-8.
2. Про Національну програму інформатизації : Закон України від 04.02.1998 р. № 74/98-BP. URL. https://zakon.rada.gov.ua/ laws/show $/ 74 / 98-\%$ D0\%B2\%D1\%80\#Text

3. Про затвердження Концепції створення Єдиної державної автоматизованої паспортної системи: Постанова Кабінету Міністрів України від 20.01.1997 р. № 40 . URL. https://zakon.rada.gov.ua/laws/show/40$\underline{97}$

4. Інструкція про порядок складання звіту про використання програмних продуктів і комп'ютерних мереж на 1 січня 1997 року за формою N 3-інф» : Наказ Міністерства статистики України від 09.07.1996 p. № 207. URL. https://zakon.rada.gov.ua/ laws/show/z0394-96/ed 19970924/find?text

5. Про затвердження Авіаційних правил України «Обслуговування/управління аеронавігаційною інформацією» : Наказ Державної авіаційної служби України від 11.04 .2016 p. № 258. URL. https://zakon. rada.gov.ua/laws/show/z0687-16\#Text

6. Про затвердження Регламенту роботи Засвідчувального центру Національного банку України: Постанова Національного банку України від 08.09.2014 р. № 553. URL. https://zakon.rada.gov.ua/laws/show/ v0553500-14\# Text

7. Цивільний кодекс України: Закон України від 16.01.2003 р. № 435-IV. URL. https://zakon.rada.gov.ua/laws/card/435-15/ conv

8. Про затвердження Порядку створення, ведення та доступу до відомостей Єдиної інформаційної бази даних про внутрішньо переміщених осіб : Постанова Кабінету Міністрів України від 22.09.2016 р. № 646. URL. https://zakon.rada.gov.ua/laws/ show/646-2016-\%D0\%BF\#Text

9. Аазор Я. (2019) Поняття та види інформаційних систем. IT право: проблеми і перспективи розвитку в Україні. Матеріали міжнародної науково-практичної конференції (Аьвів, 19 листопада 2019 р.). URL. http://aphd.ua/publication-146/

10. Про захист інформації в інформаційно-телекомунікаційних системах : Закон України від 05.07.1994 р. № 80/94-BP. URL. https://zakon.rada.gov.ua/laws/card/80/94$\% \mathrm{D} 0 \% \mathrm{~B} 2 \% \mathrm{D} 1 \% 80$ 


\section{Адміністративне право}

\section{АНОТАЦІЯ}

у статті досліджуються проблеми правового регулювання формування та використання публічних баз даних з позииій чинного інформаиійного законодавства у контексті європейсъкої інтегращй Украӥни із застосування загальнонаукових і спеиіально-юридичних методів дослідження правових явищ. Передумовою формування та використання публічних баз даних є публічні інтереси, визнані державою, та забезпечені правом суспільно значущі потреби в систематизованому обліку в иифрровій формі найбільш важливих для держави відомостей з метою подальшого використання в діяльності органів публічної влади. Аналізується легальне визначення поняття «база даних та розкриваються різні інтерпретаииї зазначеного поняття, які розділено на три групи в залежності від інформативності та змісту. Розглядається співвідношення баз даних $i$ реєстраиійних обліків у контексті інформаиійних ресурсів діяльності органів державной та місцевої влади, правові режими формування та використання баз даних. Вказано, що функиіонування баз даних має технологічні засади, це, у свою чергу, вимагає юридичної інтерпретачиї та включення у сферу дї права. Розкрито співвідношення понять «база даних» та «банк даних», указано що в окремих випадках поняття розглядають як рівнозначні в інших як складова частина. Розрізненість правового регулювання призводить до змішання правових режимів баз даних і різних видів інформациї облікового характеру, підміни понять. Недосконалість законодавства в галузі публічних баз даних виражена у відсутності єдиних вимог та правил ббормування та використання публічних баз даних, у невизначеності законодавчих дефініиій поняття «база даних» у публічній сфері. 3 метою вдосконалення правового регулювання в галузі публічних баз даних необхідне прийняття законодавчого акта, що створюе нормативноправову основу для фбормування та використання баз даних у сбері публічного управління.

Встановлено, шо у загальному вигляді, в залежності від підходу до правового регулювання баз даних, сукупність нормативних актів в иій галузі можна подати так: перша група - закони та підзаконні нормативні акти, що закріплюють правовий режим конкретної бази даних як інбормаційного ресурсу; друга група - адміністративні регламенти надання послуг з ведення баз даних i з надання інформациї з баз даних; третю групу нормативних актів складають ті, у яких тільки згадується необхідність створення та ведення баз даних у певній сфері суспільних відносин.

Ключові слова: база даних, банк даних, інформаиійна система, інбормаиійні ресурси, публічна влада, законодавство, правове регулювання.

\section{SUMMARY}

The article examines the problems of legal regulation of the formation and use of public databases from the standpoint of current information legislation in the context of Ukraine's European integration in the application of general scientific and special legal methods of studying legal phenomena. Prerequisite for the formation and use of public databases are public interests recognized by the state and provided by law socially significant needs for systematic accounting in digital form of the most important information for the state for further use in the activities of public authorities. The legal definition of the term "database" is analyzed and different interpretations of this concept are revealed, which are divided into three groups depending on the informativeness and content. The ratio of databases and registration records in the context of information resources of state and local authorities, legal regimes of formation and use of databases is considered. It is stated that the functioning of databases has technological principles, which in turn requires legal interpretation and inclusion in the scope of law. The relationship between the concepts of "database" and "database" is revealed, it is indicated that in some cases the concepts are considered equivalent in others as an integral part. The diversity of legal regulation leads to a mixture of legal regimes of databases and different types of information of an accounting nature, the substitution of concepts. Imperfection of legislation in the field of public databases is expressed in the absence of uniform requirements and rules for the formation and use of public databases, in the uncertainty of legal definitions of the concept of "database" in the public sphere. In order to improve the legal regulation in the field of public databases, it is necessary to adopt a legislative act that creates a legal basis for the formation and use of databases in the field of public administration.

It is established that in general, depending on the approach to the legal regulation of databases, the set of regulations in this area can be presented as follows: the first group - laws and bylaws that establish the legal regime of a particular database as an information resource; the second group administrative regulations for the provision of services for the maintenance of databases and the provision of information from databases; the third group of regulations consists of those that only mention the need to create and maintain databases in a particular area of public relations.

Key words: database, data bank, information system, information resources, public authorities, legislation, legal regulation. 